\title{
Pengaruh Pengetahuan dan Penerapan Perppu Nomor 1 Tahun 2017 tentang Akses Informasi Keuangan terhadap Kepatuhan Wajib Pajak (Studi Empiris Wajib Pajak Orang Pribadi di Cikarang Utara)
}

\author{
Khaerani Mahdinur Awlia \\ khaerani.mahnidur@gmail.com \\ Accounting Study Program, Faculty of Business \\ Universitas Presiden, Cikarang, Indonesia \\ Whereson Siringoringo \\ wheresonringo@gmail.com \\ Accounting Study Program, Faculty of Business \\ Universitas Presiden, Cikarang, Indonesia
}

\begin{abstract}
The purpose of this study is to find out how much influence the knowledge and application of Perppu number 1 of 2017 about access to financial information on taxpayer compliance with individual taxpayers in North Cikarang. Research data obtained through questionnaires distributed to registered taxpayers and have NPWP in North Cikarang as many as 105 samples, sampling is done by non probality sampling, and data analysis method used is multiple linear regeresi analysis. The result of this research concludes that Knowledge of Perppu number 1 year 2017 about access of financial information have positive and significant influence to taxpayer compliance (value at $\mathrm{t}$ count $2,354>$ value at $\mathrm{t}$ table 1,983 ) application of Perppu number 1 year 2017 about access of financial information have influence positive and significant to taxpayer compliance (value at $t$ count of 4.528> value at $t$ table 1,983) and tested simultaneously Knowledge and Application of Perppu number 1 year 2017 about access of financial information positive and significant to tax compliance ( $\mathrm{F}$ count 17,54> 3.08).
\end{abstract}

Keywords: Knowledge, Implementation, Perppu Number 1 Year 2017, Taxpayer Compliance

\begin{abstract}
Abstrak
Penelitian ini bertujuan untuk mengetahui pengaruh pengetahuan dan penerapan perppu nomor 1 tahun 2017 tentang akses informasi keuangan terhadap kepatuhan wajib pajak pada wajib pajak orang pribadi di Cikarang Utara. Data penelitian didapatkan melalui kuesioner yang disebarkan kepada wajib pajak yang terdaftar dan memiliki NPWP di Cikarang Utara sebanyak 105 sampel, pengambilan sampel dilakukan dengan cara non probality sampling, dan metode analisis data yang digunakan adalah analisis regeresi linear berganda. Hasil penelitian menyimpulkan bahwa Pengetahuan Perppu nomor 1 tahun 2017 tentang akses informasi keuangan memiliki pengaruh yang positif dan signifikan terhadap kepatuhan wajib pajak (nilai pada t hitung 2,354 > nilai pada t tabel 1,983) penerapan Perppu nomor 1 tahun 2017 tentang akses informasi keuangan memiliki pengaruh yang positif dan signifikan terhadap kepatuhan wajib pajak ( nilai pada t hitung 4,528 > nilai pada t tabel 1,983) dan diuji secara bersamaan Pengetahuan dan Penerapan Perppu nomor 1 tahun 2017 tentang akses informasi keuangan bernilai positif dan signifikan terhadap kepatuhan pajak (F hitung 17,54 $>3,08)$.
\end{abstract}

Kata kunci: Pengetahun, Penerapan, Perppu Nomor 1 Tahun 2017, Kepatuhan Wajib Pajak 


\section{PENDAHULUAN}

Indonesia termasuk kedalam kategori negara berkembang, pembangunan kesejahteraan dan kualitas hidup masyarakatnya menjadi tujuan utama pemerintah untuk mencapai cita-cita seperti yang tertuang di dalam pembukaan Undang-Undang Dasar tahun 1945. Proses pembangunan tersebut memerlukan biaya yang cukup besar, baik dalam bentuk biaya belanja rutin pemerintah maupun biaya belanja modal, yang setiap tahun besar kebutuhan pembiayaan tersebut terus menerus meningkat, sehingga pemerintah harus berupaya mencari dan memperoleh sumber pendapatan yang mampu memenuhi kebutuhan pembiayaan tersebut.

Siringoringo (2015) mengatakan bahwa, dekade ini telah terjadi pergesaran sumber pendapatan utama di dalam APBN, yaitu dari sumber pendapatan yang berasal dari sektor Migas ke Non-migas. Semakin terkurasnya sumber daya alam yang berasal dari sektor Migas yang tidak dapat diperbaharui, membuat pemerintah mengalihkan target pendapatan utamanya ke sektor Non migas terutama pendapatan yang berasal dari penerimaan pajak. Penerimaan negara dari pajak menjadi sumber penerimaan terbesar yang dimasukkan dalam APBN untuk digunakan dalam membiayai pengeluaran pemerintah dalam mencapai pembangunan bangsa.

Sejauh ini, kinerja penerimaan pajak belum mampu mencapai target penerimaan yang telah ditetapkan dalam APBN. Pendapatan negara dari sektor pajak dalam APBN dari tahun ke tahun belum dapat di realisasikan $100 \%$. Berdasarkan data yang dirilis oleh Kementerian Keuangan target penerimaan pajak untuk tahun 2012 adalah sebesar Rp 1016 milyar dan realisasi penerimaan pajak sebesar Rp 980,5 milyar, tahun 2013 target penerimaan pajak sebesar Rp 1.148 milyar dan realisasi penerimaan pajak sebesar Rp 1.077,3 milyar, tahun 2014 target penerimaan pajak sebesar Rp 1.246 milyar dan realisasi penerimaan pajak sebesar Rp 1.146,8 milyar, tahun 2015 target penerimaan pajak sebesar Rp 1.489,3 milyar dan realisasi penerimaan pajak sebesar Rp 1.240,4 milyar dan tahun 2016 target penerimaan pajak sebesar Rp 1.539,1 milyar dengan realisasi penerimaan pajak hanya sebesar Rp 1.105 milyar dan persentasi realisasi penerimaan pajak tahun 2015 (81,5\%) dan 2016 (83\%) merupakan yang terburuk dalam sepuluh tahun terakhir.

Rendahnya realisasi penerimaan pajak dari target yang sudah ditetapkan dalam APBN, diperkuat oleh fakta tingkat kepatuhan wajib pajak di Indonesia yang masih sangat rendah, hal ini bisa dilihat dari pencapaian tax ratio yang menjadi salah satu indikator yang digunakan dalam mengukur kepatuhan Wajib Pajak masih sangat rendah dan bahkan masih tertinggal di bandingkan dengan negara ASEAN lainnya. Berdasarkan data BPS, pada tahun 2014 tax ratio Indonesia hanya mampu mencapai $12,2 \%$ di bandingkan dengan negara Flipina 16,7\%, dan Malaysia 15,9\%, dan sangat jauh tertinggal dari rata-rata OECD 34,2\%.

Rendahnya tax ratio yang menggambarkan rendahnya tingkat kepatuhan Wajib Pajak adalah merupakan masalah yang sanagt serius dan harus ditangani secara bersama-sama oleh Pemerintah dan Wajib Pajak itu sendiri, jika tidak, maka pemerintah harus mencari sumber pendanaan lain untuk menutupi defisit anggaran pembiayaan yang terjadi, yaitu salah satunya adalah melalui pinjaman atau hutang, dan jika hal ini terus menerus terjadi maka, Negara ini akan kehilangan otoritasnya sebagai negara yang berdaulat. Oleh karena itu dari sisi Pemerintah diperlukan kejelasan dan kemudahan dalam melaksanakan Ketentuan, Peraturan dan undangUndang Perpajakan, sedangkan dari sisi Wajib Pajak diperlukan tindakan yang nyata dalam melaksanakan hak dan kewajiban perpajakannya secara benar dan tepat sesuai dengan Ketentuan, Peraturan dan Undang-Undang Perpajakan yang berlaku.

Untuk meningkatkan kekuatan hukum dalam menciptakan kepatuhan Wajib Pajak, Pemerintah telah menerbitkan Peraturan Pemerintah Pengganti Undang-undang nomor 1 Tahun 2017 sebagaimana pelaksanaannya diperjelas dalam Peraturan Menteri Keuangan Nomor 73/PMK.03/2017, yang menyatakan bahwa dengan penetapan peraturan ini, Direktorat Jendral Pajak (DJP), berwenang memperoleh aksess informasi keuangan demi kepentingan perpajakan, 
yaitu akses informasi yang dapat diperoleh dari pihak berwenang yang memenuhi kategori sesuai dengan standar dalam pertukaran informasi keuangan untuk memenuhi perjanjian internasional pada bidang pajak, pihak yang berwenang seperti Lembaga Jasa Keuangan, pasar modal, asuransi, dan jasa keuangan lainnya. Informasi keuangan yang didapat oleh Direktorat Jendral Pajak dapat dijadikan sebagai alat untuk mendeteksi akan terjadinya penyelewengan pajak yang dilakukan oleh Wajib Pajak.

Self Assement System, sebagai sistem pemungutan pajak yang dianut oleh Indonesia, Wajib Pajak diberikan hak seluas-luasnya untuk menghitung dan melaporkan kewajiban perpajakannya sendiri. Dalam menjalankan hak dan kewajiban perpajakan tersebut, maka Wajib Pajak harus berpedoman kepada Ketentuan, Peraturan dan Undang-Undang Perpajakan yang berlaku, agar hak dan kewajiban perpajakannya dapat dilaksanakan dengan benar dan tepat. Salah satunya adalah pengetahuan akan Peraturan Pemerintah Pengganti Undang-undang nomor 1 Tahun 2017 sebagaimana pelaksanaannya diperjelas dalam Peraturan Menteri Keuangan Nomor 73/PMK.03/2017 yang telah diterbitkan dan ditetapkan oleh Pemerintah. Untuk itu Wajib Pajak harus memiliki pengetahuan yang memadai atas Peraturan Pemerintah Pengganti Undang-undang nomor 1 Tahun 2017 dan Peraturan Menteri Keuangan Nomor 73/PMK.03/2017 tersebut, sehingga Wajib Pajak dapat dengan benar melakukan hak dan kewajibannya sebagai Wajib Pajak (Muljono 2009).

Penelitian lebih lanjut perlu dilakukan untuk melihat pengaruh dari pengetahuan dan penerapan Perppu No 1 tahun 2017 tentang akses informasi keuangan terhadap kepatuhan wajib pajak dalam melaksanakan hak dan kewajiban perpajakan pemerintah dan wajib pajakn dalam usaha meningkatkan tingkat realisasi pendapatan negara dari sektor pajak sehingga dapat memberikan gambaran kepada pemerintah sebagai regulator dan kepada wajib pajak sebagai subjek pajak akan penting atau tidaknya Perppu tersebut dalam melindungi pelaksanaan hak dan kewajiban perpajakan pemerintah maupun wajib pajak.

Berdasarkan uraian latar belakang masalah di atas, maka masalah yang diajukan dalam penelitian ini adalah:

1. Apakah pengetahuan Wajib Pajak terhadap Perppu nomor 1 tahun 2017 berpengaruh terhadap kepatuhan wajib pajak?

2. Apakah penerapan Perppu nomor 1 tahun 2017 berpengaruh terhadap kepatuhan Wajib Pajak?

3. Apakah pengetahuan Wajib Pajak dan penerapan Perppu nomor 1 tahun 2017 secara bersama-sama berpengaruh terhadap kepatuhan Wajib Pajak?

\section{KAJIAN TEORI}

\section{Theory Of Planned Behaviour (TPB)}

Perilaku Wajib Pajak untuk memiliki niat patuh atau tidak patuh dalam melaksanakan hak dan kewajiban perpajakannya, akan terlebih dahulu memikirkan apa yang akan menjadi implikasi dari keputusannya tersebut, hal ini dapat diterangkan dalam theory of planned behavior yang dikemukakan oleh Ajzen (1991) yang memaparkan bahwa manusia merupakan makhluk yang memiliki pemahaman rasionalitas yang akan mempergunakan semua informasi yang diperolehnya secara sistematis untuk memutuskan apakah akan melakukan atau tidak melakukan perilaku tertentu. TPB yang digunakan sebagai teori yang mendukung penelitian ini adalah Control Beliefs dan Behavioral Beliefs.

Control Beliefs yang dikemukakan dalam TPB menjelaskan bahwa seseorang dapat percaya diri untuk melakukan atau tidak melakukan suatu perilaku diperoleh oleh orang tersebut melalui pengetahuannya akan perilaku tersebut dan fasilitas yang ada untuk melaksanakan perilaku tersebut. Hal ini menjelaskan bahwa dalam melaksanakan suatu perilaku diperlukan 
ada nya pengetahuan yang memadai akan perilaku tersebut, sehingga perilaku bisa di lakukan atau tidak dilakukan. Selain pengetahuan Control Beliefs juga memerlukan fasilitas untuk digunakan untuk dapat melakukan atau tidak melakukan perilaku tersebut.

Behavioral Beliefs dalam TPB memberikan penjelasan bahwa untuk melakukan suatu tindakan yang diinginkan seharusnya sesuai dengan apa yang didapatkan, dengan kata lain seseorang yang melakukan suatu tindakan yang diinginkan didasari oleh keinginan untuk memperoleh hasil yang diharapkan, baik hasil yang didapatkan bermanfaat maupun tidak.

Teori ini memiliki pemahaman yang sesuai dengan penelitian ini, dimana pengetahuan wajib pajak akan penerapan dari Perppu No 1 tahun 2017, tentang akses informasi keuangan serta pengetahuan wajib pajak akan hasil yang dia peroleh apabila patuh atau tidak patuh dalam menjalankan hak dan kewajiban perpajakannya dapat mempengaruhi wajib pajak dalam memutuskan niatnya untuk patuh atau tidak patuh dalam memenuhi hak dan kewajiban perpajakannya. Seseorang yang memiliki niat untuk menjadi patuh dan tidak patuh dalam melakukan hak dan kewajiban pepajakan akan dapat dilaksanakan apabila wajib pajak memiliki pengetahuan tentang bagaimana penerapan perppu tersebut harus dilaksanakan sebagai mana mestinya, sementara akibat dari patuh tidak patuhnya seorang wajib pajak akan memberikan dampak bagi seorang wajib pajak berupa dikenakan atau tidak dikenakan sanksi.

\section{Pengertian Pajak}

Pajak adalah biaya yang wajib dikeluarkan oleh rakyat kepada negara yang terutang oleh orang pribadi atau badan atas kewajibannya membayar iuran berdasarkan Undang-undang. Pembayaran pajak merupakan kontribusi dan kewajiban seorang warga negara dan juga peran serta yang dilakukan warga negara untuk pembiayaan negara dan pembangunan nasional.

Yolina (2009) mendefinisikan pajak adalah suatu pemberian yang berlandasan undang undang memiliki sifat memaksa tanpa mendapatkan imbalan apapun yang diberikan oleh wajib pajak, dengan tujuan guna memenuhi kebutuhan negara untuk kemakmuran masyarakat. Pajak adalah iuran yang diberikan kepada kas negara yang berlandaskan undang-undang dengan tidak menerima jasa timbal (kontraprestasi) yang secara langsung diterima negara guna membayar pengeluaran umum (Mardiasmo, 2009). Pajak memiliki peran cukup besar dalam kehidupan negara. Pajak memiliki fungsi sebagai (1) Fungsi Anggaran (Budgetair), (2) Sebagai Alat Pengatur (Regulerend) (3) Sebagai Alat Penjaga Stabilitas (4) Fungsi Redistribusi Pendapatan.

\section{Pengetahuan Perppu Nomor 1 Tahun 2017 Tentang Akses Informasi Keuangan}

Mandhira et al, (2017) Pada tanggal 8 Mei 2017 telah disahkan Perppu yang berkepentingan dalam perpajakan yakni Perppu Nomor 1 tahun 2017 mengenai akses informasi keuangan. Perpajakan menganut prinsip-prinsip yang bersifat universal, yaitu bersifat efisiensi, keadilan, kemudahan administrasi dan pengoptimalisasi dalam peningkatan penerimaan negara. Peraturan dalam perpajakan tetap berdasarkan prinsip-prinsip perpajakan, oleh karena itu harapanya yakni untuk kepentingan perpajakan adalah untuk meningkatkan keadilan pengenaan pajak, konsistensi dan transparan, dan menunjang kepastian hukum.

Menurut KBBI, segala sesuatu hal yang harus diketahui dan memiliki kepandaian disebut sebagai pengetahuan. Dan pengetahuan pajak adalah salah satu langkah terbukanya pemikiran bagi wajib pajak melalui sosialisasi dan pelatihan. Wajib pajak perlu mendasari pengetahuan pajak sehingga untuk melakukan peningkatan kepatuhann wajib pajak, maka harus memahami akan pengetahuan segala peraturan dan tata cara yang ada dalam perpajakan. Suatu informasi yang dapat digunakan oleh wajib pajak ketika akan mengambil keputusan, melakukan tindakan dan menjalankan hak dan kewajiban adalah pengetahuan mengenai pajak (Carolina, 2009).

Dalam hal ini Perppu nomor 1 tahun 2017 tentang akses informasi, termasuk dalam pengetahuan perpajakan yang harus dimiliki oleh wajib pajak. Semakin luas pengetahuan seseorang maka motivasi yang dimiliki dalam menjalankan kepentingan membayar pajak 
tersebut akan semakin baik, hal ini didasari pada orang yang memiliki pengetahuan yang cukup luas terutama dalam hal kepentingan pajak yang digunakan untuk keperluan public investment (Istanto, 2010).

Sehingga dapat disimpulkan bahwa pengetahuan pajak adalah pelaksanaan hak dan kewajiban diikuti oleh adanya informasi mengenai pajak yang dapat digunakan sebagai dasar pengambilan keputusan dan melakukan tindakan sehubungan dengan pelaksanaan hak dan kewajibannya. Pengetahuan pajak memiliki beberapa indicator, terdiri dari: (1) Rasa keadilan bagi wajib pajak (2) untuk mengecek kebenaran SPTnya (3) kepastian hukum pelaksanaan hak dan kewajiban wajib pajak (4) pelaksanaan pertukaran informasi sesuai Perppu nomor 1 tahun 2017.

\section{Penerapan Perppu nomor 1 Tahun 2017 Tentang akses informasi keuangan}

Kebijakan mengenai penerapan Perppu nomor 1 tahun 2017 tentang akses informasi keuangan untuk kepentingan perpajakan merupakan langkah pemerintah untuk mengatasi permasalahan tax ratio di Indonesia. Tax ratio Indonesia pada tahun 2016 adalah sebesar $10,36 \%$, nilai ini merupakan rasio yang terendah jika dibandingkan negara lain yang mempunyai rata-rata nilai tax ratio sebesar $15 \%$. Hal tersebut dikarenakan faktor dari sejumlah wajib pajak diluar negeri yang belum melaporkan hartanya kepada Direktur Jenderal Pajak (DJP) berwenang dan belum dikenai pajak di Indonesia. Upaya yang dilakukan oleh pemerintah dalam menjalankan program yang diperlukan dalam pemberian akses informasi keuangan dan keterbukaan informasi keuangan bagi otoritas perpajakan, yakni dengan diterbitkannya Perppu nomor 1 tahun 2017 tentang akses informasi keuangan Untuk Kepentingan Perpajakan.

Menurut Mandhira et al, (2017) lembaga otoritas perpajakan dalam hal ini yaitu DJP yang bekerja untuk memperoleh informasi keuangan wajib pajak yang berada didalam negeri dan diluar negeri untuk kepentingan perpajakan, selain itu upaya ini adalah sebagai penguatan basis data perpajakan demi memenuhi kebutuhan keberlanjutan efektivitas kebijakan tax amnesty dan memenuhi kebutuhan penerimaan pajak. Dalam hal ini pemerintah mengharapkan kebijakan Perppu nomor 1 tahun 2017 ini dapat mencapai target penerimaan pajak.

Dibentuknya Perppu ini dasarnya untuk memudahkan dalam menerima dan mendapatkan akses informasi keuangan untuk kepentingan perpajakan serta melaksanakan perjanjian internasional dibidang. Direktur Jenderal Pajak (DJP) berhak untuk memiliki kewenangan dalam memperoleh informasi yang berhubungan dengan keuangan yang didapatkan dari lembaga yang memenuhi standar kategori dalam perjanjian internasional demi kepentingan pertukaran informasi dibidang perpajakan diantaranya sektor pasar modal, perbankan, asuransi dan entitas keuangan lainnya.wajib pajak tidak perlu khawatir dengan diterapkanya Perppu nomor 1 tahun 2017 karena sejatinya tidak ada kewenangan yang diberikan tanpa batas.

Indikator dalam penerapan Perppu nomor 1 tahun 2017 tentang akses informasi keuangan diantaranya (1) memenuhi kebutuhan penerimaan pajak (2) mendapatkan informasi yang dibutuhkan oleh perpajakan (3) menjalankan komitmen dalam perjanjian Internasional (AEOI) (4) menghindari kerugian yang signifikan bagi indonesia sebagai anggota G20 (5) akses bagi otoritas perpjakan. 


\section{Kepatuhan Wajib Pajak}

Sesuai KBBI, kata patuh berarti suatu tindakan dalam mentaati peraturan yang berlaku. Siringoringo (2015) menyatakan bahwa, keputusan yang dimiliki oleh suatu kelompok atau individu dalam mentaati dan mejalani sebuah aturan yang terdapat dilingkungan disebut patuh. Kepatuhan pajak terbagi menjadi 2 macam, yakni:

1. Kepatuhan formal, dimana kewajiban perpajakan secara formal dipenuhi oleh wajib pajak berdasarkan dengan ketentuan dan peraturan pajak, indikator kepatuhan formal meliputi: (1) wajib pajak harus mendaftarkan diri, (2) memiliki NPWP, (3) ketepatan waktu dalam menyampaikan SPT ke KPP, (4) memperhitungkan dan membayar pajak dengan jumlah yang tepat.

2. Kepatuhan material, dimana ketentuan material perpajakan dipenuhi oleh wajib pajak sesuai dengan ketentuan dan peraturan pajak. Contohnya wajib pajak yang telah memenuhi kepatuhan material, yaitu apabila pengisian SPT dilakukan dengan berlandaskan pada kejujuran, dan dilakukan dengan benar sesuai ketentuan pajak. Menurut Rahayu (2010) kepatuhan material meliputi (a) Kesiapan wajib pajak untuk memberikan informasi mengenai pajak apabila dibutuhkan. (b) Ketika melakukan proses administrasi wajib pajak memiliki sikap kooperatif (tidak menyusahkan). (c) Keyakinan sebagai warga negara yang baik dengan melaksakan kewajiban pajak.

\section{Hipotesis}

Pengetahuan wajib pajak mengenai Perppu nomor 1 Tahun 2017 tentang Akses Informasi Keuangan Untuk Kepentingan Perpajakan diharapkan akan meningkatkan kepatuhan pajak. Informasi yang dimiliki oleh wajib pajak akan mempengaruhi mereka terhadap kepatuhan wajib pajak dan wajib pajak dapat mengetahui kewajiban yang harus dilakukan dalam hal perpajakan. Semakin banyak informasi yang mereka ketahui maka akan membantu mereka untuk bisa mematuhi aturan yang berlaku.

Pada penelitian sebelumnya, Menurut Trisia \& Dedi Haryanto (2006) mengatakan bahwa adanya pengaruh dari perbedaan pengetahuan bagi wajib bpajak yang melakukan kewajibannya secara patuh dan yang melakukan kewajibannya secara tidak patuh. Sedangkan menurut Zuhdi, Topowijono, Azizah (2015) menjelaskan bahwa, meningkatnya kepatuhan pada wajib pajak dipengaruhi oleh pengetahuan perpajakan yang baik yang dimiliki wajib pajak.

Upaya yang dilakukan oleh pemerintah dalam menjalankan program yang diperlukan dalam pemberian akses informasi keuangan dan keterbukaan informasi keuangan bagi otoritas perpajakan, yakni dengan diterbitkannya Perppu nomor 1 tahun 2017 tentang akses informasi keuangan untuk kepentingan perpajakan. Menurut Mandhira, Diatmika, dan Yasa (2017) menyatakan bahwa diterapkannya Perppu nomor 1 tahun 2017 berpengaruh terhadap penerimaan pajak. 


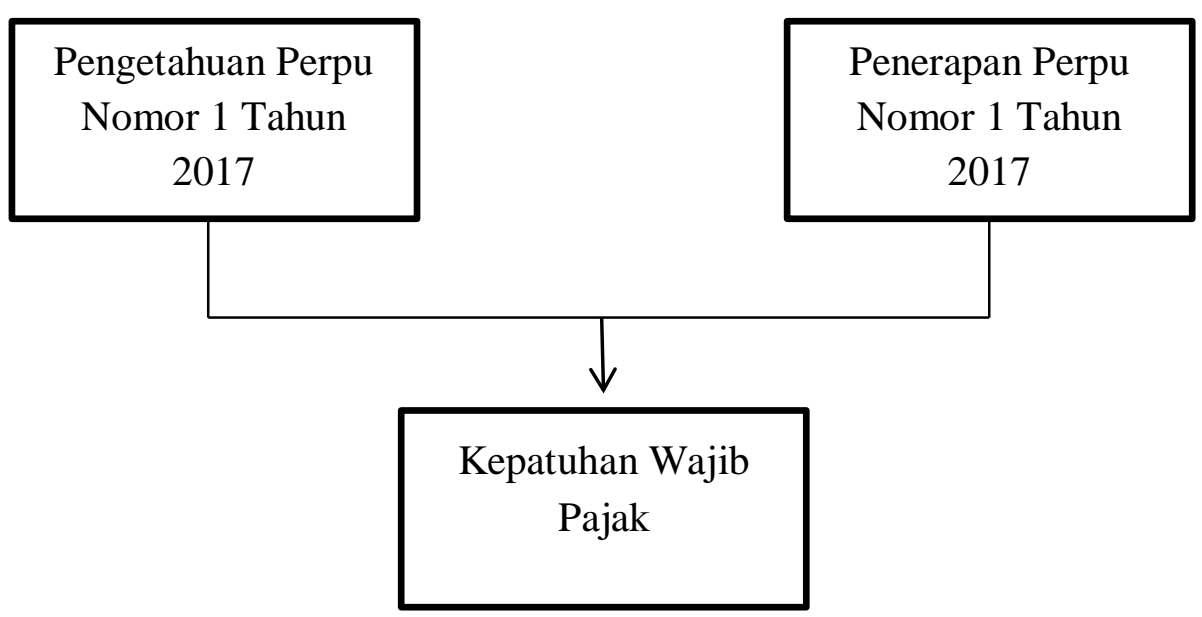

Gambar 1. Kerangka Pemikiran Teoritis

$\mathrm{H}_{1}$ : Pengetahuan terhadap Perppu Nomor 1 tahun 2017 berpengaruh positif terhadap kepatuhan Wajib Pajak.

$\mathrm{H}_{2}$ : Penerapan Perppu Nomor 1 tahun 2017 berpengaruh positif terhadap kepatuhan Wajib Pajak.

$\mathrm{H}_{3}$ : Pengetahuan dan penerapan Perppu Nomor 1 tahun 2017 secara bersama berpengaruh positif terhadap kepatuhan Wajib Pajak.

\section{METODE PENELITIAN}

Penelitian ini menggunakan metode kuantitatif yang mengacu kepada pengetahuan dan penerapan Perppu nomor 1 tahun 2017 tentang akses informasi keuangan pada saat penelitian dilakukan dan penilaian terhadap permasalahan tersebut diperoleh dari kuesioner yang diberikan kepada wajib pajak di Cikarang Utara.

Pengumpulan data primer dilakukan melalui survei dengan cara membagikan kuesioner kepada responden melalui jaringan internet (computer-delivered survei). Peneliti memakai kuesioner yang dirancang sendiri untuk mengetahui jawaban responden atas setiap variabel. Seluruh wajib pajak orang pribadi yang memilikii NPWP yang terdapat di wilayah Cikarang Utara akan dijadikan sebagai sampel. Banyaknya jumlah wajib pajak yang terdaftar di Cikarang Utara menentukan pengambilan sampel pada penelitian ini yaitu dengan menggunakan Accidental Sampling. Sugiyono (2008) mengatakan bahwa sampling accidental metode pengambilan sampel secara nomor random (acak) yang dapat dilakukan dengan cara memilih sampel sesuai kehendak peneliti.

Metode Penentuan sampel apabila tidak diketahui jumlah populasinya, maka dalam penelitian ini Roscoe (1975) dalam Uma Sekaran (1992) mengatakan bahwa penentuan jumlah sampel yakni sebaiknya ukuran sampel di antara $30 \mathrm{~s} / \mathrm{d} 500$ elemen, dan ukuruan sampel dalam penelitian multivariate (analisis regresi) harus beberapa kali lebih besar seperti 5 hingga 10 kali dari jumlah indikator variabel/terikat yang akan dianalisis.

Mengacu penjelasan di atas, jumlah sample yang akan diuji pada penelitian ini sebanyak 7 kali dari jumlah indikator,jumlah indikator pada penelitian ini sebanyak 15 indikator, sehingga jumlah sampel yang akan diuji sebanyak 105 sampel.

\section{Operasionalisasi Variabel}

Variabel yang digunakan dalam penelitian ini dibedakan menjadi 2 variabel yaitu variabel independen dan variabel dependen. Variabel independen terdiri atas: 
1. Pengetahuan atas Perppu No.1 tahun 2017 yang diukur dengan menggunakan indikator Rasa keadilan, Kebenaran SPTnya, Kepastian hukum, Pelaksanaan Perppu nomor 1 tahun 2017 dengan menggunakan alat ukur skala likert 1-5 poin.

2. Penerapan Perppu No.1 Tahun 2017 yang dikur dengan menggunakan indikator Kebutuhan Wajib Pajak, Perolehan Informasi, Pemenuhan Komitmen AEOI, dan Akses Informasi dengan menggunakan alat ukur skala liker 1-5 poin.

Variable dependen dalam penelitian ini adalah Kepatuhan Wajib Pajak yang diukur dengan menggunakan indikator Kepatuan Formal dan Kepatuhan Material dengan menggunakan alat ukur skala likert 1-5 poin.

\section{Analisis Data}

Pengumpulan data primer dilakukan melalui survei dengan cara membagikan kuesioner kepada responden. Kuesioner yang akan digunakan dalam memperoleh data responden dalam penelitian ini adalah kuesioner yang dibuat sendiri sesuai dengan indikator-indikator variable penelitian ini. Hartono (2011) menjelaskan bahwa sebuah instrumen penelitian harus mampu mengukur secara nyata dan akurat tentang apa yang seharusnya diukur dari konsep penelitian. Oleh karena itu, akan terlebih dahulu dilakukan uji validitas dan realibitas terhadap kuesioner penelitian yang digunakan dalam penelitian ini. Validitas erat kaitannya dengan tujuan penelitian, seberapa nyata pengujian dapat mencapai sasaran penelitian (Hartono, 2011). Instrumen penelitian dikatakan valid apabila dapat mengukur secara aktual apa yang hendak diukur pada penelitian tersebut. Suatu Variabel dapat dikatakan valid apabila: nilai $t$ hitung $>t$ tabel maka item pernyataan dinyatakan valid. Sekaran (2006) menjelaskan bahwa reliabilitas yakni suatu nilai yang dapat menunjukan konsistensi parameter atau alat pengukur apabila pengukuran dilakukan secara berulang-ulang pada suatu gejala yang sama. Dalam penelitian ini, hasil pengukuran reliabilitas dengan Cronbrach's alpha memiliki rentang nilai 0 ke 1, di mana nilai terendah yang dapat diterima adalah 0.60 - 0.70 (Hair et al., 2009)

Adapun metode-metode yang digunakan dalam mengolah data yaitu uji deskriptif, uji asumsi klasik, dan uji hipotesis. Setelah tahapan uji asumsi klasik dapat terpenuhi semua, maka dapat dilanjutkan analisis untuk model regresi yaitu analisis regresi linier berganda. Multiple regresi atau analisis regresi berganda merupakan analisis yang dipakai untuk model regresi yang mempunyai variabel bebas lebih dari satu dengan rumus $Y=a+b_{1} x_{1}+b_{2} X_{2}+. . b_{n} x_{n}$

Penerimaan hipotesis yang diajukan adalah menggunakan uji parsial dan uji simultan . uji parsial dilakukan dengan membandingkan nilai $t$, yaitu jika nilai t hitung $>$ dari $t$ tabel $(1,983)$, maka $\mathrm{H} 0$ ditolak dan Ha diterima. Uji simultan dilakukan dengan membandingkan nilai F, yaitu jika nilai $F_{\text {hitung }}>F_{\text {tabel }}(3.08)$, maka Ha diterima. 


\section{HASIL DAN PEMBAHASAN}

Dari Hasil uji validitas dan reabilitas diperoleh hasil sebagai berikut :

Tabel 1. Uji Validitas

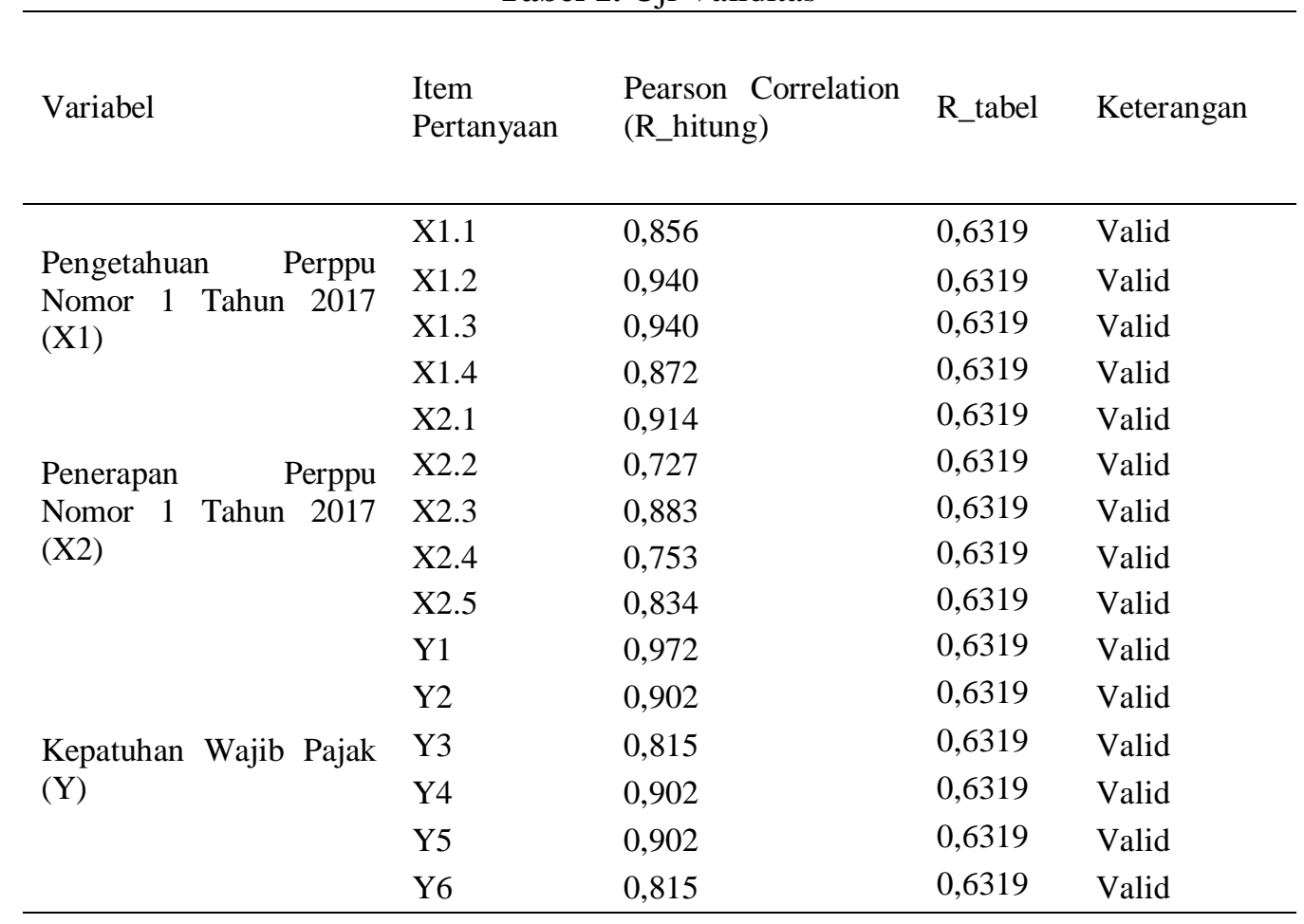

Hasil untuk menguji validitas dengan $d f=8(10-2)$ pada tingkat signifikansi $\alpha=0,05$ atau 0,01 dari hasil tersebut diketahui bahwa setiap indikator memiliki nilai $r$ hitung $>r$ tabel sehingga semua indikator penyataan tersebut dinyatakan valid sebagai instrumen penelitian.

Tabel 2. Uji Reliabilitas

\begin{tabular}{lll}
\hline Variabel & Cronbach'c Alpha & Keterangan \\
\hline Pengetahuan Perppu Nomor 1 Tahun 2017 (X1) & 0,917 & Reliabel \\
Penerapan Perppu Nomor 1 Tahun 2017 (X2) & 0,871 & Reliabel \\
Kepatuhan Wajib Pajak (Y) & 0,943 & Reliabel \\
\hline
\end{tabular}

Nilai dari Cronbach's alpha untuk masing-masing variabel lebih besar dari 0,6. Berdasarkan ketentuan yang telah disebutkan sebelumnya maka semua variabel yang digunakan untuk penelitian reliabel.

\section{Statistik Deskriptif}

Variabel pada penelitian ini merupakan sebuah data yang memiliki nilai yang dapat diukur dan dapat dijelaskan dengan gambaran secara umum melalui mean atau rata rata nilai, standar deviasi, nilai minimum dan nilai maksimum. Hasil analisis statistik deskriptif dapat dilihat dari tabel 3 berikut: 
Tabel 3. Statistik Deskriptif

\begin{tabular}{|c|c|c|c|c|c|}
\hline & $\mathrm{N}$ & Minimum & Maximum & Mean & $\begin{array}{l}\text { Std. } \\
\text { Deviation }\end{array}$ \\
\hline $\begin{array}{l}\text { Pengetahuan Perppu Nomor } 1 \\
\text { Tahun } 2017 \text { (X1) }\end{array}$ & 105 & 8 & 20 & 14,61 & 2,676 \\
\hline $\begin{array}{l}\text { Penerapan Perppu Nomor } 1 \\
\text { Tahun } 2017 \text { (X2) }\end{array}$ & 105 & 12 & 25 & 18,93 & 2,863 \\
\hline Kepatuhan Wajib Pajak (y) & 105 & 12 & 30 & 25,09 & 4,027 \\
\hline Valid N (listwise) & 105 & & & & \\
\hline
\end{tabular}

\section{Analisis Asumsi Klasik}

Asumsi klasik yang diuji yaitu: uji normalitas, uji heterokedastisitas, dan uji multikolinieritas. Pada uji normalitas didapatkan hasil bahwa pada uji kolmogorov smirnov probalitas (Asymtotic Significance) memiliki nilai 0,078 yaitu probalitas > 0,05 maka dapat dikatakan distribusi populasi normal.

Tabel 4. Hasil Uji Normalitas (One-Sample kolmogorov-smirnov Test)

\begin{tabular}{l|l} 
& \multicolumn{1}{c}{$\begin{array}{l}\text { Unstandardized } \\
\text { Residual }\end{array}$} \\
\hline Kolmogorov-Smirnomorv Z & 0,078 \\
Asymp. Sig. (2-tailed) & 0,123 \\
\hline
\end{tabular}

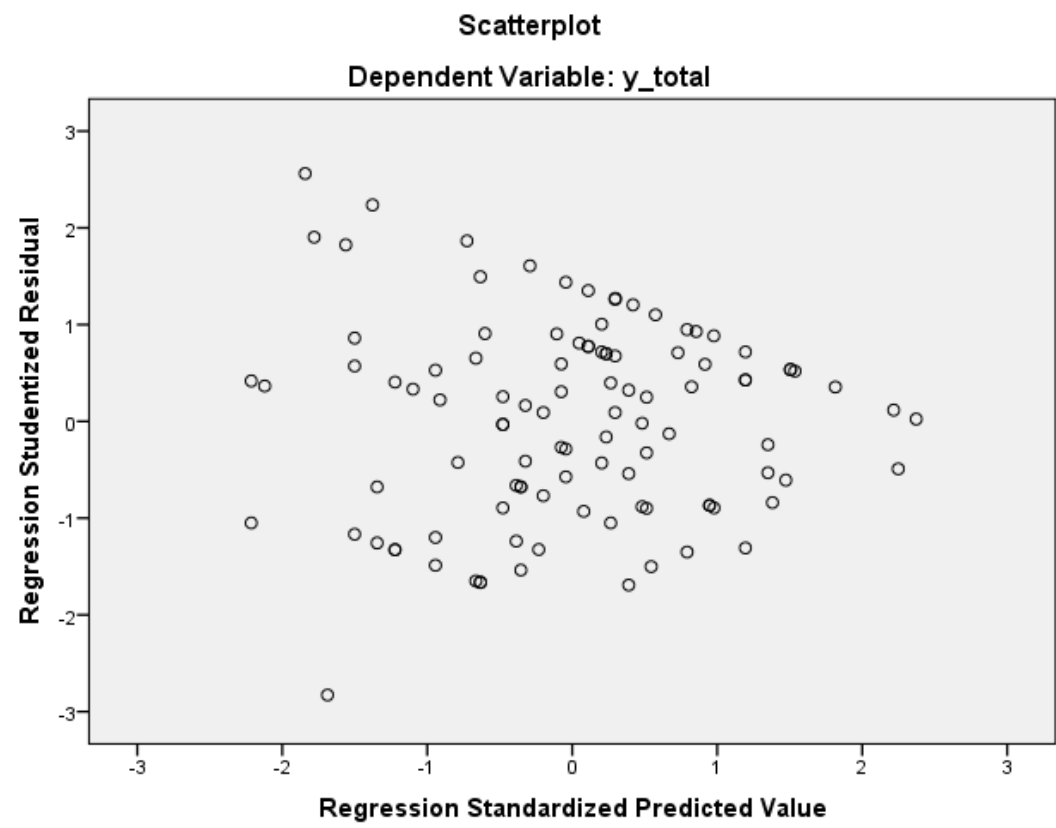

Gambar 2. Hasil Uji Heterokesdastisitas 
Hasil pengujian dikatakan model regresi baik karena data penelitian setelah dilakukan uji heterokedastisitas memperoleh data yang menyebar dan tidak membentuk pola maka pada data tersebut tidak mengalami heterokedastisitas.

Tabel 5. Hasil Uji Multikolinearitas

\begin{tabular}{llll}
\hline \multirow{2}{*}{ Model } & \multicolumn{2}{l}{ Collinearity Statistics } & \multirow{2}{*}{ Keterangan } \\
\cline { 2 - 3 } & Tolerance & VIF & \\
\hline $\begin{array}{l}\text { Pengetahuan Perppu Nomor 1 Tahun } \\
2017\end{array}$ & 0,917 & 1,090 & Bebas Multikolinearitas \\
$\begin{array}{l}\text { Penerapan Perppu Nomor 1 Tahun } \\
2017\end{array}$ & 0,917 & 1,090 & Bebas Multikolinearitas \\
\hline
\end{tabular}

Hasil uji multikolinearitas didapat bahwa keseluruhan variabel independen memilki nilai tolerance $>0,1$ dan nilai $\mathrm{VIF} \leq 10$ dengan nilai tolerance pada masing masing variabel bebas sebesar 0.917 dimana nilai $0.917>0.10$ dan nilai VIF pada masing-masing variabel bebas sebesar 1.090 dimana nilai $1.090<$ 10sehingga dapat disimpulkan bahwa tidak terjadi multikolinearitas antar variabel independen.

\section{Analisis Uji Hipotesis}

Hipotesis yang diuji pada penelitian ini dengan menggunakan metode analisis berganda (multiple regression) untuk mengetahui pengaruh pengetahuan dan penerapan Perppu nomor 1 tahun 2017 terhadap kepathan wajib pajak. Pada pengujian ini menguji suatu hubungan antara variabel independen dengan variabel dependen. Model regresi pada penelitian ini yaitu : $\mathrm{Y}=$ $9.718+0.316 \mathrm{X} 1+0.568 \mathrm{X} 2$

Tabel 6. Hasil Uji Parsial (Uji t)

\begin{tabular}{|c|c|c|c|c|c|}
\hline \multirow[t]{2}{*}{ Model } & \multicolumn{2}{|c|}{$\begin{array}{l}\text { Unstandardized } \\
\text { Coefficients }\end{array}$} & \multirow{2}{*}{$\begin{array}{l}\text { Unstandardize } \\
\text { d Coefficients } \\
\text { Beta }\end{array}$} & \multirow[b]{2}{*}{$\mathrm{T}$} & \multirow[b]{2}{*}{ Sig. } \\
\hline & B & Std. Error & & & \\
\hline (Constant) & 9,718 & 2,631 & & 3,694 & 0,000 \\
\hline Pengetahuan $\quad$ Perppu & & & & & \\
\hline $\begin{array}{l}\text { Nomor } 1 \text { Tahun } 2017 \\
\text { Penerapan Perppu Nomor }\end{array}$ & 0,316 & 0,134 & 0,210 & 2,354 & 0,020 \\
\hline 1 Tahun 2017 & 0,568 & 0,125 & 0,404 & 4,528 & 0,000 \\
\hline
\end{tabular}

Variabel pengetahuan Perppu Nomor 1 Tahun 2017 (X1) didapatkan t hitung sebesar 2,354 dan nilai t tabel sebesar 1,983 dan dengan nilai signifikan sebesar 0,020. Sehingga nilai t hitung yang dimiliki pada variabel pengetahuan Perppu Nomor 1 Tahun 2017 sebesar 2,345 > 1,983 dan memiliki nilai signifikan sebesar 0,020 < 0,05 maka dapat dinyatakan bahwa variabel bebas mengenai Perppu Perppu Nomor 1 Tahun 2017 mempengaruhi terhadap kepatuhan wajib pajak.

Variabel Penerapan Perppu Nomor 1 Tahun 2017 (X2) mempunyai nilai t hitung sebesar 4,528 dan nilai t tabel sebesar 1,983 dan nilai signifikan sebesar 0,000. Artinya nilai t hitung variabel Penerapan Perppu Nomor 1 Tahun $20174.528>1.983$ dan nilai signifikan 0,000 < 0,05 sehingga dapat disimpulkan bahwa variabel bebas mengenai Penerapan Perppu Nomor 1 Tahun 2017 mempengaruhi terhadap kepatuhan wajib pajak. 
Tabel 7. Hasil Uji R-Square

\begin{tabular}{lllll}
\hline Model & $\mathrm{R}$ & $\begin{array}{l}\mathrm{R} \\
\text { Square }\end{array}$ & $\begin{array}{l}\text { Adjusted } \\
\text { Square }\end{array}$ & $\begin{array}{l}\text { Std. Error of } \\
\text { the Estimate }\end{array}$ \\
\hline 1 & 0,506 & 0,256 & 0,241 & 3,507 \\
\hline
\end{tabular}

Hasil uji $R$ square adalah sebesar 0,256, hal ini berarti bahwa 25,6\% kepatuhan wajib pajak dapat dijelaskan oleh variable independen dalam penelitian ini, yaitu variabel Pengetahuan dan variable Penerapan Perppu nomor 1 tahun 2017, sedangkan 74,4\% lainnya dapat dijelaskan oleh variable lain diluar variable penelitian ini.

Tabel 8. Hasil Uji Simultan (Uji F)

\begin{tabular}{llllll} 
& & & & & \\
Model & Sum of Square & Df & Mean Square & F & Sig. \\
\hline Regression & 431,56 & 2 & 215,78 & 17,54 & 0,000 \\
Residual & 1254,67 & 102 & 12,30 & & \\
Total & 1686,23 & 104 & & & \\
\hline
\end{tabular}

F hitung memilki nilai sebesar 17.54 dan didapat $\mathrm{F}$ tabel sebesar 3.08 dan tingkat signifikan sebesar 0.000 sehingga nila $F$ hitung lebih besar dari pada $F$ tabel yaitu sebesar $17.54>3.08$ dengan nilai signifikan lebih kecil dari 0,05 yaitu sebesar 0,000<0,05. Hal ini dalam uji simultan menunjukan bahwa jika variabel pengetahuan Perppu Nomor 1 Tahun 2017 (X1) dan variabel Penerapan Perppu Nomor 1 Tahun 2017 (X2) diuji secara bersamaan atau simultan mempengaruhi terhadap kepatuhan wajib pajak.

\section{KESIMPULAN}

\section{Simpulan}

Hasil analisis dan pengujian pengaruh pengetahuan Perppu nomor 1 tahun 2017 berpengaruh positif dan signifikan terhadap kepatuhan wajib pajak, ditunjukkan dari hasil analisis yang diperoleh bahwa nilai t hitung 2,354 > nilai t tabel 1,983 dan dengan tingkat nilai signifikansi 0,020. (2) Hasil analisis dan pengujian pengaruh penerapan Perppu nomor 1 tahun 2017 berpengaruh positif dan signifikan terhadap kepatuhan wajib pajak, ditunjukkan dari hasil analisis yang diperoleh bahwa nilai t hitung 4,528 > nilai t tabel 1,983 dan dengan tingkat nilai signifikansi 0,000. (3) Hasil analisis dan pengujian pengaruh pengetahuan dan penerapan Perppu nomor 1 tahun 2017 secara bersamaan berpengaruh positif dan signifikan terhadap kepatuhan wajib pajak sehingga ditunjukkan dari hasil analisis yang diperoleh bahwa nilai $\mathrm{F}$ hitung 17,54 > nilai $F$ tabel 3,08 dan dengan tingkat nilai signifikansi 0,000.

Hasil penelitian ini menunjukkan bahwa variable pengetahuan memiliki pengaruh yang positif dan signifikan terhadap kepatuhan wajib pajak oleh karena itu Pemerintah dan Wajib Pajak harus secara bersama sama melakukan usaha yang nyata dalam upaya meningkatkan peningkatan pengetahuan wajib pajak terhadap atauran-aturan perpajakan yang diterbitkan oleh pemerintah, karena dengan pengetahuan yang tinggi terhadap peraturan perpajakan akan memudahkan wajib pajak melaksanakan hak dan kewajiban perpajakannya secara patuh.

Variabel Penerapan Perppu nomor 1 tahun 2017 juga memiliki pengaruh positif yang siginifikan terhadap kepatuhan wajib pajak, hal ini membuktikan bahwa besarnya akses yang dimiliki oleh fiskus terhadap keuangan wajib pajak akan membuat wajib pajak tidak dapat menyembunyikan penghasilan-penghasilan wajib pajak yang terkait dengan objek pajak, sehingga wajib pajak cenderung untuk patuh terhadap pelaksanaan hak dan kewajiban 
perpajakannya dari pada menghadapi konsekuensi dari pelanggaran yang dapat ditelusuri dari rekening wajib pajak tersebut.

\section{Keterbatasan Penelitian}

Keterbatasan dalam penelitian ini salah satunya adalah peneliti menggunakan lingkup daerah yang sempit, sehingga jumlah wajib pajak yang digunakan dalam penelitian ini hanya 105 responden dan responden penelitian ini tidak dibatasi hanya wajib pajak yang memiliki rekening koran sebesar 1 milyar.

\section{Saran}

Peran Pemerintah sebagai regulator dalam meningkatkan kepatuhan Wajib Pajak agar dapat menerbitkan, mensosialisaikan dan menerapkan peraturan perpajakan yang berkelanjutan bagi Wajib Pajak. Bagi Wajib Pajak agar berperan aktif untuk meningkatkan pengetahuan perpajakannya. Peneliti selanjutnya yang ingin mengembangkan penelitian ini agar melakukan penambahan variabel baru yang belum diuji dalam penelitian.

\section{DAFTAR PUSTAKA}

Badan Pusat Statistik. Retrieved November 20, 2017, from https://www.bps.go.id/statictable/2014/09/12/1179/anggaran-pendapatan-negaramiliar-rupiah-2007-2017.html

Carolina, V. (2009). Pengetahuan Pajak. Jakarta: Salemba Empat.

Diah N. M, Putu G. D, \& Nyoman P. Y. (2017). Pengaruh Implementasi Perpu No.1 Tahun 2017 tentang Akses Informasi Keuangan Untuk Kepentingan Perpajakan dan Kesadaran Wajib Pajak terhadap Penerimaan Pajak pada Kantor Pelayanan Pajak Pratama Singaraja. e-journal S1 Ak Universitas Pendidikan Ganesha, 8(2).

Elisa V, (2017) Saldo Minimum Wajib Pajak Lapor. Retrieved June 06, 2017, from https://www.cnnindonesia.com/ekonomi/20170608002320-78-220209/pemerintahrevisi-saldo-minimum-wajib-lapor-pajak-jadi-rp1-m

Hair, JR; C, J.F Black W.; J, Babin B; E, \& Anderson R. (2009). Multivariate Data Analysis (Seveth ed). Upper Saddle River: Prentice Hall.

Hartono, J. (2011). Metodologi Penelitian Bisnis. Yogyakarta: Fakultas Ekonomika dan Bsnis UGM.

Istanto, Y. (2010). Pengaruh Strategi Keunggulan Bersaing dan Positioning Terhadap Kinerja Koperasi Serba Usaha Di Kabupaten Sleman Yogyakarta. Buletin Ekonomi, 8(2).

Kemenkeu. (2017). Anggaran Pendapatan dan Belanja Negara. Retrieved November 10, 2017 , from Kementrian Keuangan Republik Indonesia: www.kemenkeu.go.id

Mardiasmo. (2011). Perpajakan. Yogyakarta: Edisi Revisi Andi.

Muljono, D. (2009). Pemotongan dan Pemungutan Pph Pasal 25/29.

Pranadata. (2014). Pengaruh Pemahaman Wajib Pajak, Kualitas Perpajakan, dan Pelaksanaan Sanksi Pajak terhadap Kepatuhan Wajib Pajak Oramg Pribadi pada KPP Pratama Batu. Fakultas dan Bisnis Universitas Brawijaya, Malang.

Rahayu, S. K. (2010). Perpajakan Indonesia Konsep dan Aspek Formal. Yogyakarta: Graha Ilmu.

Republik Indonesia. (2017). Peraturan Pemerintah Pengganti Undang- undang Nomor 1 Tahun 2017 Tentang Akses Informasi Keuangan Untuk Kepentingan Perpajakan

Roscoe 1975 Dikutip dari Uma Sekaran. (1992). Metode Penelitian Bisnis. Jakarta: Salemba Empat. 
Sekaran Uma. (2006). Metodolohgi Penelitian Untuk Bisnis. Jakarta: Salemba Empat.

Siringiringo, W. (2015). Pengaruh Penerapan Good Governance dan Whistleblowing System Terhadap Kepatuhan Wajib Pajak Orang Pribadi dengan Resiko Sanksi Pajak Sebagai Variabel Moderating (Studi Empiris Terhadap Wajib Pajak Orang Pribadi di Kota Bekasi). Jurnal Akuntansi, XIX(02), 207-224.

Sugiyono. (2008). Metode Penelitian Kuantitatif Kualitatif dan R\&D. Bandung: Alfabeta. Yolina. (2009). Dasar-Dasar Akuntansi Perpajakan. Yogyakarta: Tabora Media. 